\title{
Daytime and nighttime vertical migrations of Alexandrium tamarense in the St. Lawrence estuary (Canada)
}

\author{
Juliette Fauchot $^{1, *}$, Maurice Levasseur ${ }^{2}$, Suzanne Roy ${ }^{1}$ \\ ${ }^{1}$ Institut des Sciences de la Mer de Rimouski, Université du Québec à Rimouski, 310 allée des Ursulines, Rimouski, \\ Québec G5L 3A1, Canada \\ ${ }^{2}$ Université Laval, Département de biologie, Pavillon Alexandre-Vachon, Ste-Foy, Québec G1K 7P4, Canada
}

\begin{abstract}
A population of the toxic dinoflagellate Alexandrium tamarense was followed in a $48 \mathrm{~h}$ survey of the St. Lawrence estuary in order to determine its ability to perform vertical migrations in nature. A. tamarense performed daytime and nighttime migrations during our study. Cells were generally found close to the surface during daytime, started their descent down to the nitracline before sunset, and returned toward the surface after sunrise (with an estimated migration speed of $2 \mathrm{~m} \mathrm{~h}^{-1}$ ). Our results suggest that $A$. tamarense cells were able to fulfill their nitrogen requirement while migrating to the deep layers during the night. During the day, A. tamarense cells adjusted to daily fluctuations in light intensity using their motile capacity and aggregated at a depth where light intensity did not exceed $300 \mu \mathrm{mol}$ photons $\mathrm{m}^{-2} \mathrm{~s}^{-1}$. The nutritional status of the A. tamarense population near the surface was determined at the onset of the $48 \mathrm{~h}$ study during a set of onboard nutrient addition experiments. Results from these experiments indicated that the net growth rate of $A$. tamarense was controlled by phosphate availability, while the biomass was dependent on nitrate availability. These results suggest that the ability of $A$. tamarense to reach the deep nitrate reservoir at night allows this species to reach elevated biomass as observed during red-tide events, and could push this species toward phosphate limitation in the St. Lawrence estuary.
\end{abstract}

KEY WORDS: Alexandrium tamarense - Toxic dinoflagellates · Vertical migrations · Phosphate · Nitrate $\cdot$ Light $\cdot$ St. Lawrence estuary

\section{INTRODUCTION}

The ability of harmful dinoflagellates to perform vertical migrations represents a key feature of their bloom dynamics. Their capacity to move vertically in the water column allows them to access the deep nitrogen pool at night or to avoid high surface irradiance during the day (Cullen \& Horrigan 1981, Heaney \& Eppley 1981, Passow 1991, MacIntyre et al. 1997). In addition, the interplay between their migration pattern and regional circulation shapes their spatio-temporal distribution (Anderson \& Stolzenbach 1985, Donaghay \& Osborn 1997). Understanding the migratory pattern of dinoflagellates is thus crucial if we are to understand, and eventually model, their physiology and ecology.
Vertical migration patterns have been described for many dinoflagellate species. Gonyaulax polyedra (Heaney \& Eppley 1981), G. catenata (Passow 1991) and Gymnodinium splendens (Cullen \& Horrigan 1981) migrate to the subsurface during the day to avoid high surface irradiance, especially when nitrogenlimited. Some of these species and others (Prorocentrum minimum, P. micans, Ceratium furca, Olsson \& Granéli 1991; Alexandrium tamarense, MacIntyre et al. 1997) exhibit vertical migrations to deeper layers during the night to take up nitrogen. This migratory behavior can be controlled by phototaxis, geotaxis, diel rhythms or cellular nutritional status (Cullen \& Horrigan 1981, Passow 1991, MacIntyre et al. 1997). There are important differences in migration patterns and 
their control factors among dinoflagellates, so site- and species-specific investigations are a prerequisite in order to fully understand their ecophysiology.

Dense toxic blooms of Alexandrium tamarense occur every summer in the St. Lawrence estuary (eastern Canada), resulting in paralytic shellfish poisoning episodes (Blasco et al. 2003). These blooms are generally confined to nutrient-poor brackish water plumes (Therriault et al. 1985, Weise et al. 2002), suggesting that vertical migrations to the deep nitrate reservoir are essential for their development and maintenance. We know from a laboratory study that an $A$. tamarense strain from the St. Lawrence estuary has the capacity to cross the thermocline and to migrate down to the deep nitrogen reservoir when nitrogen-deficient (MacIntytre et al. 1997). However, such migratory behavior has never yet been observed in the field. During their laboratory study, MacIntytre et al. (1997) found that vertical migrations of $A$. tamarense were controlled by phototaxis, diel rhythms and the nutritional status of the cells. The direct extrapolation of the results obtained by MacIntyre et al. (1997) to field conditions is hazardous since other dinoflagellate species have already showed different migration patterns in situ than in vitro (Passow 1991). The existence of such behavior in situ in the St. Lawrence estuary would have important consequences on the dynamics of $A$. tamarense blooms. First, it would give A. tamarense an advantage over other phytoplankton species in the nitrogen-poor surface waters of the estuary during the summer. Second, as hypothesized by Fauchot et al. (2005), the ability of $A$. tamarense to perform nocturnal vertical migrations in situ and acquire nitrate at depth

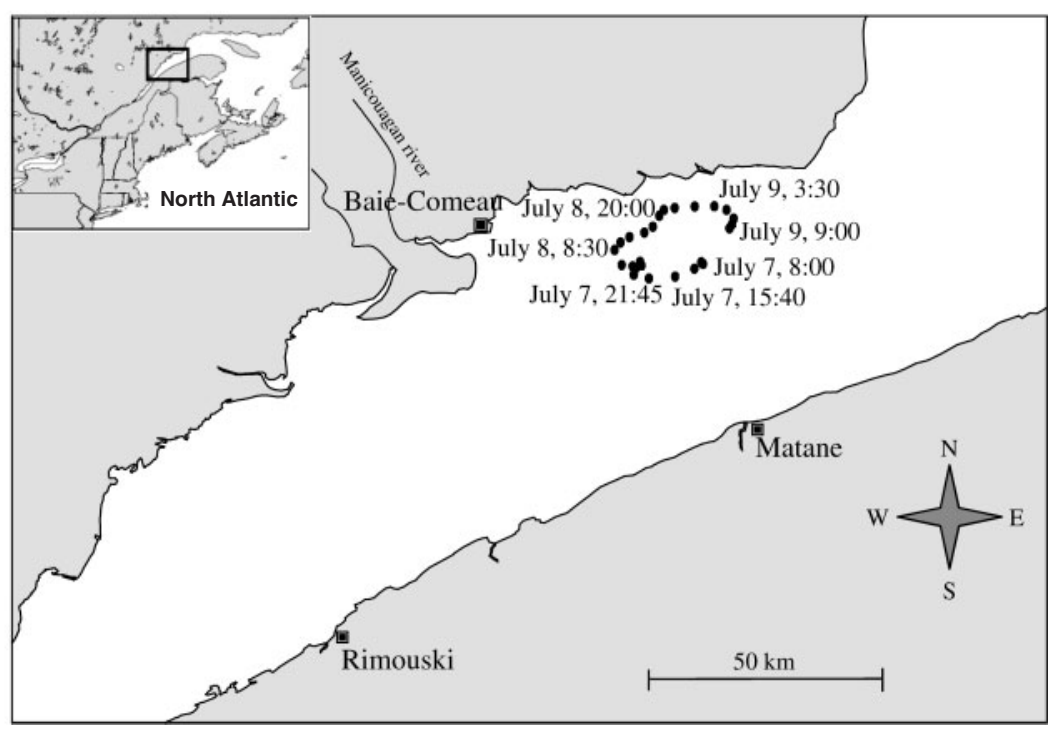

Fig. 1. Drifter trajectory with the location of the different samplings in the St. Lawrence estuary during the $48 \mathrm{~h}$ survey, from 7 July 2000 at 08:00 h to 9 July 2000 at 09:00 h may push this species towards phosphate limitation in surface waters. Finally, the interactions between vertical migrations and the estuarine circulation prevailing in the St. Lawrence estuary are likely to affect the distribution of the blooms and, thus, the geographical extent of their impacts.

The main objective of this study was to determine whether Alexandrium tamarense could perform vertical migrations to the deep nitrogen reservoir during the course of a $48 \mathrm{~h}$ survey while a bloom was taking place in the St. Lawrence estuary. In addition, the nutritional status of the $A$. tamarense population near the surface was determined at the onset of the study during a set of onboard nutrient addition experiments.

\section{MATERIALS AND METHODS}

Survey (48 h). The survey was conducted in the NE part of the Lower St. Lawrence estuary near BaieComeau, from 7 to 9 July 2000 (Fig. 1) onboard the C.C.G.S. 'Martha L. Black'. The day before, the area was surveyed to locate a patch of Alexandrium tamarense. Then, a drifter was deployed to track the water mass containing the A. tamarense population. The drogue was located at a depth between 3 and $5 \mathrm{~m}$. The trajectory followed by the drifter during the $48 \mathrm{~h}$ survey is presented in Fig. 1, from 7 July at 08:00 h to 9 July at 09:00 h.

Sampling at the drifter. The sea was calm during the sampling period and, in order to prevent disturbances to the vertical structure of the water column and the behavior of Alexandrium tamarense, the main ship stayed away (more than $2 \mathrm{~km}$ ) from the drifter, and samples were collected from a zodiac inflatable boat. In addition, the engines of the zodiac were turned down when approaching the buoy. Every $2 \mathrm{~h}$ during the survey, a shallow ( 0 to $40 \mathrm{~m}$ ) CTD cast was made and water was sampled at 5 depths (between 2 and 12 to $18 \mathrm{~m}$ ) using Niskin bottles. From July 8 at 03:30 h onwards, an additional water sample was collected at the surface with a bucket. This extra sampling depth was added following the visual observation of high phytoplankton abundance very close to the surface. Water samples were transported to the main ship in 21 carboys where subsamples were immediately taken for nutrient determination and A. tamarense enumeration. 
Nutrient addition experiment. In order to determine the initial nutrient status of the Alexandrium tamarense population in the patch, a suite of incubation experiments was performed with subsurface water $(2 \mathrm{~m})$ collected at the drifter at the first sampling time of the $48 \mathrm{~h}$ survey ( 7 July at 08:00 h), using a rosette equipped with Niskin bottles. Potential grazers of A. tamarense were removed by gentle pre-filtration with a $53 \mu \mathrm{m}$ mesh. The pre-filtered sample was then separated into 4 duplicate treatments: (1) control (no addition), (2) phosphate addition $\left(\mathrm{Na}_{2} \mathrm{HPO}_{4}+\right.$ $\mathrm{NaH}_{2} \mathrm{PO}_{4}$ added at a final concentration of $20 \mu \mathrm{M}$ ), (3) nitrate addition $\left(\mathrm{KNO}_{3}\right.$ added at a final concentration of $60 \mu \mathrm{M}$ ) and (4) nitrate + phosphate addition $\left(\mathrm{KNO}_{3}\right.$ and $\mathrm{Na}_{2} \mathrm{HPO}_{4}+\mathrm{NaH}_{2} \mathrm{PO}_{4}$ added at final concentrations of 60 and $20 \mu \mathrm{M}$, respectively). All subsamples were incubated in Whirlpak bags of $500 \mathrm{ml}$ volume (Nasco), in an on-deck incubator under in situ temperature and light conditions. The incubations lasted between 8 and $10 \mathrm{~d}$. For each treatment, 2 Whirlpak bags were taken from the incubator every day and sub-samples were collected for A. tamarense enumeration and nutrient determination. Different bags were used for each sampling time in order to ensure that the data were independent.

Alexandrium tamarense enumeration and growth determination. Water samples were preserved with acid Lugol for later identification and enumeration of A. tamarense cells using the Utermöhl technique (Lund et al. 1958). The net growth rate of the $A$. tamarense population during the incubations was calculated during the period of exponential growth following the equation:

$$
\mu=\ln \left(B_{t} / B_{t_{0}}\right) /\left(t-t_{0}\right)
$$

where $\mu$ is the net growth rate $\left(\mathrm{d}^{-1}\right)$, and $B_{t_{0}}$ and $B_{t}$ are A. tamarense abundance (cells $\mathrm{l}^{-1}$ ) at the beginning of the incubation and at the end of the exponential growth phase, respectively. Cells were enumerated once a day and since exponential growth lasted from 1 to $4 \mathrm{~d}$ in the incubations, our growth rate estimates rely on 2 to 5 data points.

Nutrient analysis. Subsamples of $5 \mathrm{ml}$ were filtered through $0.7 \mu \mathrm{m}$ Acrodisc filters (Pall-Gelman), frozen at $-80^{\circ} \mathrm{C}$ in acid-cleaned polypropylene cryogenic vials and analyzed for nitrate + nitrite, nitrite, and phosphate concentrations using a Technicon Autoanalyzer (Technicon Instruments).

Light measurements. Incident photosynthetically available radiation (PAR) was recorded at least every $2 \mathrm{~h}$ over the entire survey using a QSR-240 surface reference PAR sensor (Biospherical Instruments). A QSP-200 underwater PAR sensor was used on 8 July to determine PAR penetration at each sampling at the drifter.
Statistical analysis. A non-parametric analysis of variance (Kruskal-Wallis) was used for the comparison of the mean growth rates measured in the 4 treatments (Zar 1984). The null hypothesis $\left(H_{0}\right)$ stipulates that averages are equal between treatments. The analysis of variance was completed by Dunnett's test (Zar 1984), allowing the identification of averages that are significantly different from the control. In all tests, statistical significance was set at $\alpha=0.05$.

\section{RESULTS}

\section{Environmental conditions during the $48 \mathrm{~h}$ survey}

Vertical profiles of temperature and salinity during the $48 \mathrm{~h}$ survey are presented in Fig. 2. The structure of the water column was characterized by a surface mixed layer delimited by a thermocline located between 10 and $18 \mathrm{~m}$. Oscillations of the depth of the thermocline probably resulted from tidal waves. No obvious halocline was observed in the upper $18 \mathrm{~m}$ of the water column. Temperature and salinity in the surface mixed layer varied between 10 and $13^{\circ} \mathrm{C}$, and 26.5 and $29.5 \mathrm{psu}$, respectively. Very calm weather conditions prevailed during the survey, with wind speed never exceeding $13 \mathrm{~km} \mathrm{~h}^{-1}$. T-S diagrams for different depth layers are presented in Fig. 3. These diagrams show that the same water mass was followed at the depth of the drogue (between 3 and 5 m; Fig. 3b). A different, cooler water mass passed over the drogue at the end of the afternoon of 7 July (circled data in Fig. $3 a$, b, see also Fig. 2a). The advection of this water mass had little influence on our results since most Alexandrium cells had already migrated to deeper layers at that time (between 15:30 and 20:00 h; Fig. 4c). The T-S diagrams also show that we followed the same water mass below the drogue (5 to $10 \mathrm{~m}$, Fig. 3c). The T-S diagram for the thermocline layer (10 to 15 m, Fig. 3d) is more difficult to interpret; however, there was little change in salinity in this layer during the survey.

Nitrate and phosphate concentration profiles are presented in Fig. 4a,b. Nitrate concentrations were very low in the mixed layer $(<0.2 \mu \mathrm{M}$ above $10 \mathrm{~m})$, with the nitracline around $12 \mathrm{~m}$. Phosphate concentrations were also very low in the mixed layer $(<0.4 \mu \mathrm{M}$ above $12 \mathrm{~m})$. According to our deeper samplings on 8 and 9 July, the phosphacline was located around $16 \mathrm{~m}$, deeper than the nitracline.

\section{Alexandrium tamarense migratory behavior}

Alexandrium tamarense cells exhibited vertical migrations to deep layers during both nights of the 
a) Temperature $\left({ }^{\circ} \mathrm{C}\right)$

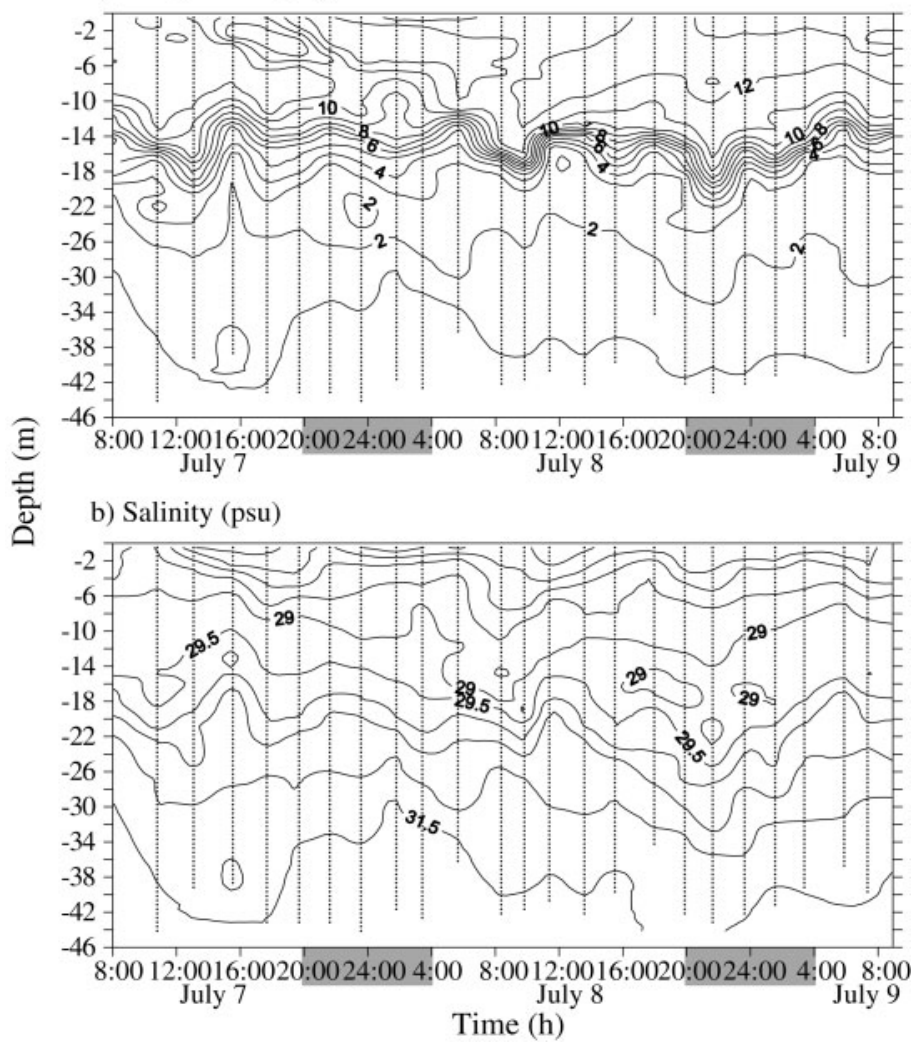

Fig. 2. Vertical profiles of (a) temperature $\left({ }^{\circ} \mathrm{C}\right.$ ) and (b) salinity during the survey. The grey bars indicate night hours

survey (Fig. 4c). Cells began to descend before sunset, at around 16:00 h on 7 July and 18:00 h on 8 July. They reached at least $12 \mathrm{~m}$, the depth corresponding to the thermocline and nitracline. During the second night, high $A$. tamarense concentrations were measured down to $18 \mathrm{~m}$ (Fig. 4c). The depth of the thermocline and nitracline was also deeper on this day, probably due to the passage of a tidal wave. The vertical distribution of $A$. tamarense may thus have also been partly affected by this tidal wave. A. tamarense cells spent $\sim 8 \mathrm{~h}$ in the deep layer $(>10 \mathrm{~m})$ on both nights. Their ascent began after 04:00 h, approximately when the sun rose. Based on the displacement rate of the peak in A. tamarense concentrations on the vertical axis, the migration speed of $A$. tamarense was estimated at 1.8 to $2 \mathrm{~m} \mathrm{~h}^{-1}$. Our results show that only part of the $A$. tamarense population migrated to deep layers. This is visible on the first night, but is even more apparent on the second night when additional subsurface samples were collected (Fig. 4c). At the end of the afternoon of the second day, $20 \%$ of the population which had accumulated at ca. 4 to $6 \mathrm{~m}$ during mid-day, migrated back to the surface and stayed there during the night, while $40 \%$ descended to the deep layer.
The migratory pattern of Alexandrium tamarense described above can best be seen in Fig. 5, where the temporal changes in cell abundance are presented for different depth intervals. A. tamarense cells first concentrated close to the surface in the early morning until 06:00 h (Fig. 5a). Then, the cells tended to avoid the surface and concentrated in the subsurface layer (Fig. 5b), and later on in the intermediate layer, with maximum concentrations at around $5 \mathrm{~m}$ (Fig. 5c). In the evening, A. tamarense concentrations increased both in the surface and deep layers (Fig. 5a,d). Cell abundance in the deep layer increased abruptly between 20:00 and 22:00 h, and then suddenly decreased on both nights. This decrease was not accompanied by an increase in cell abundance in shallower layers, suggesting that $A$. tamarense cells probably migrated deeper than the maximum sampling depth (12 and $18 \mathrm{~m}$ on the first and second nights, respectively). This hypothesis is supported by the fact that, during the survey, the $A$. tamarense abundance, integrated over the 4 layers, decreased (Fig. 6), especially during the nights and despite the fact that we increased the maximum depth of our sampling on the second night of the survey. However, we cannot rule out the possibility a) Surface layer $(0-3 \mathrm{~m})$

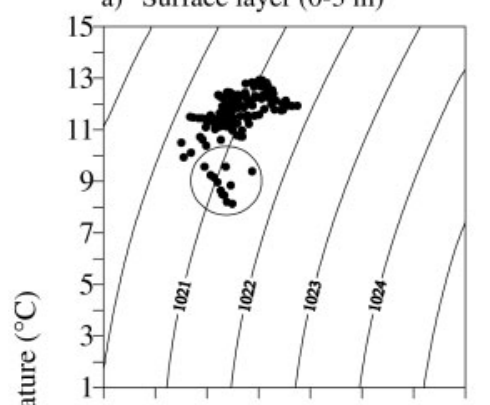

c) Intermediate layer (5-10 m)

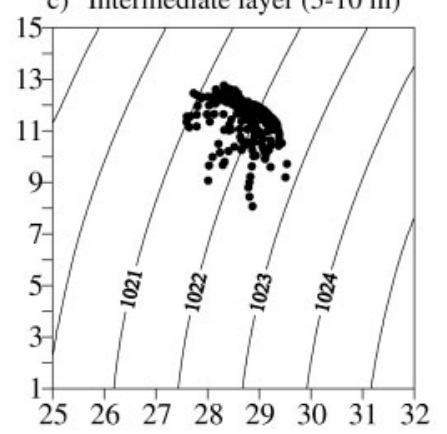

b) Subsurface layer (3-5 m)

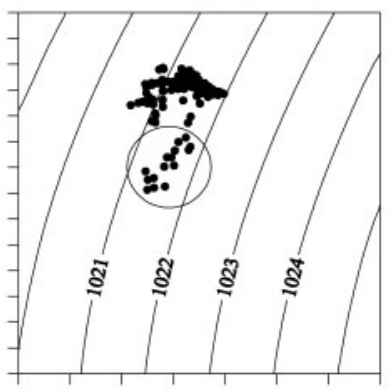

d) Deep layer (10-15 m)

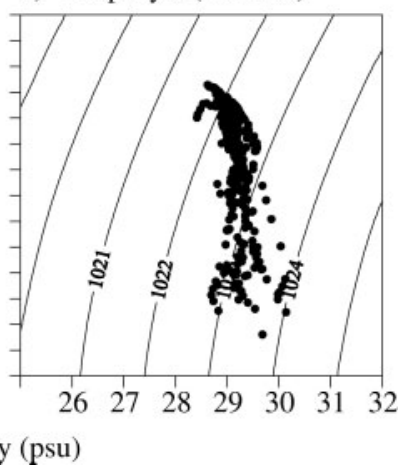

Fig. 3. T-S diagrams for the whole survey for (a) the surface layer from 0 to $3 \mathrm{~m}$; (b) the subsurface layer from 3 to $5 \mathrm{~m}$; (c) the intermediate layer from 5 to $10 \mathrm{~m}$; and (d) the deep layer from 10 to $15 \mathrm{~m}$. The circled data correspond to measurements made on 7 July between 15:40 and 19:50 h. The solid lines represent constant density lines 
a) Nitrate $(\mu \mathrm{M})$

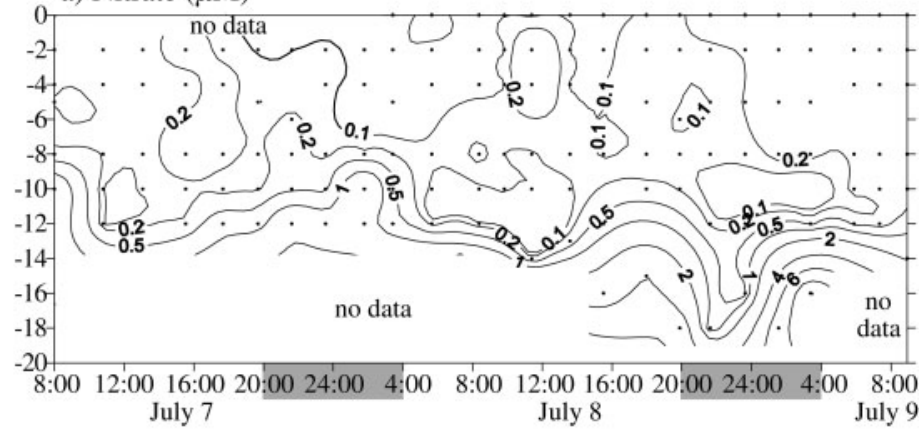

b) Phosphate $(\mu \mathrm{M})$

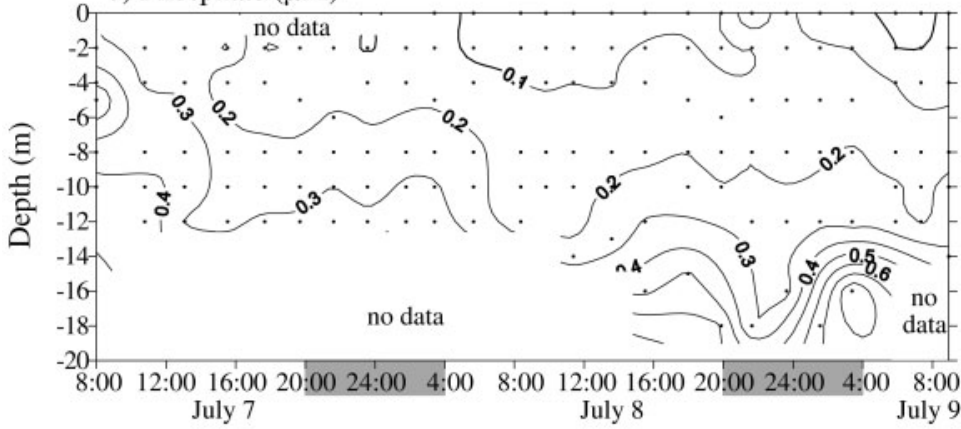

c) Abundance of A. tamarense (cells $\cdot \mathrm{l}^{-1}$ )

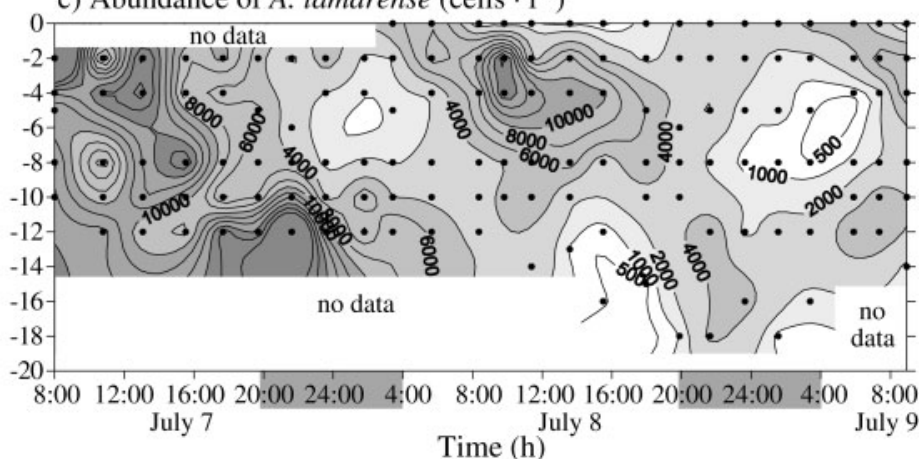

Fig. 4. Temporal variations of the vertical profiles of (a) nitrate $(\mu \mathrm{M})$; (b) phosphate $(\mu \mathrm{M})$; and (c) Alexandrium tamarense concentrations (cells $\mathrm{l}^{-1}$ ) during the $48 \mathrm{~h}$ survey. The dots indicate sampling depth. The grey bars indicate night hours

that thin layers of $A$. tamarense may have been missed out by our discrete sampling.

The relationship between the depth of the Alexandrium tamarense maximum concentration (first $6 \mathrm{~m}$ only) and light intensity for 8 and 9 July is presented in Fig. 7. Our results show that, on 8 July, the maximum concentration of A. tamarense cells was never exposed to light intensities greater than $300 \mu \mathrm{mol}$ photons $\mathrm{m}^{-2}$ $\mathrm{s}^{-1}$ since the cells gradually descended in the water column as incident light increased (Fig. 7a,b). The same pattern was observed on 9 July; A. tamarense cells started to migrate downwards when incident light exceeded $300 \mu \mathrm{mol}$ photons $\mathrm{m}^{-2} \mathrm{~s}^{-1}$. It is also clear from Fig. 7 that the almost complete avoidance of the sur-

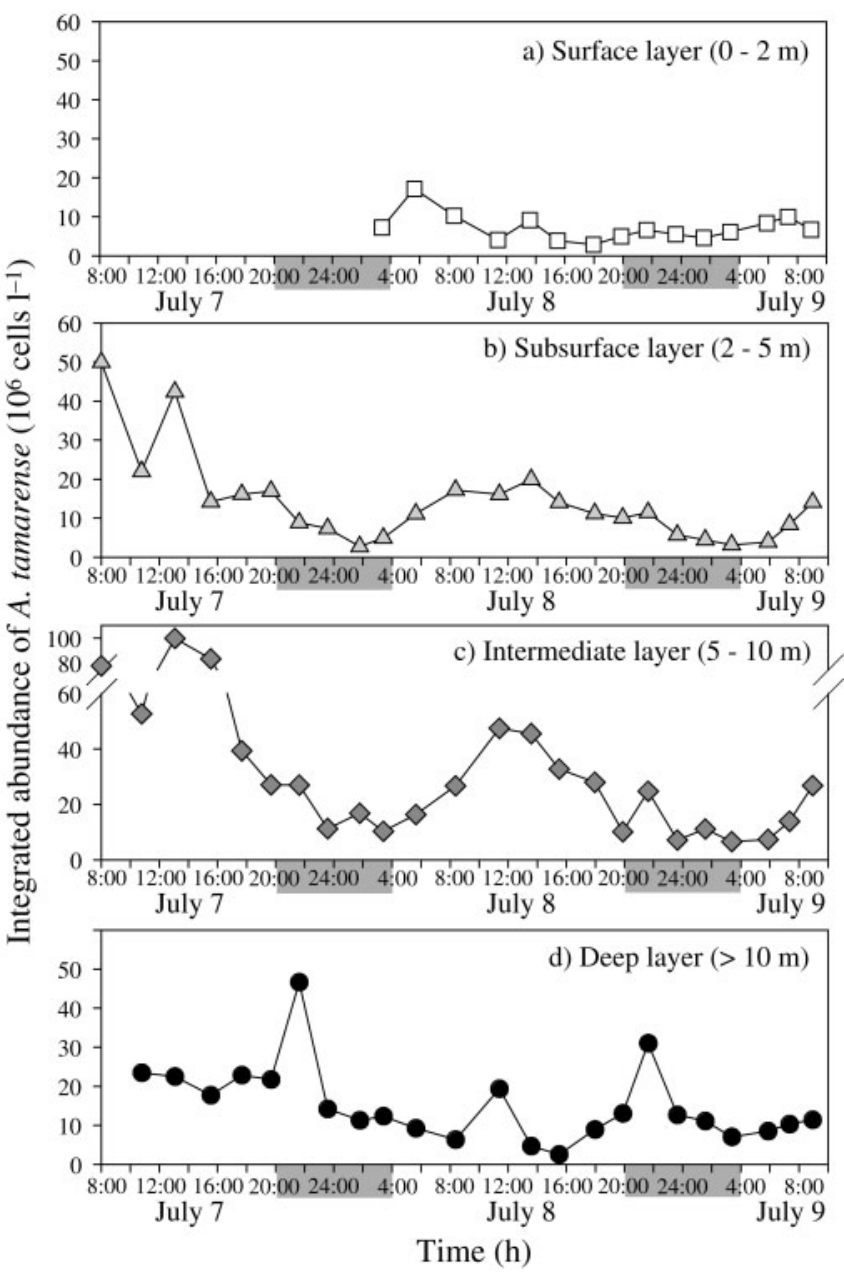

Fig. 5. Alexandrium tamarense. Temporal evolution of the integrated abundance in (a) the surface layer; (b) the subsurface layer; (c) the intermediate layer; and (d) the deep layer. The grey bars indicate night hours

face layer by $A$. tamarense cells between 13:30 and 15:30 h on 8 July (Fig. 4c) corresponded to the period of maximum incident light intensity $(\sim 2000 \mu \mathrm{mol}$ photons $\mathrm{m}^{-2} \mathrm{~s}^{-1}$ ). The cells also started to move back towards the surface as surface light intensity decreased.

\section{Alexandrium tamarense growth rate and nutrient addition experiments}

Results from the incubation experiments are presented in Fig. 8 and Table 1. The surface water used for the nutrient addition experiment was characterized by relatively high Alexandrium tamarense concentrations (>1800 cells $~^{-1}$ ) and very low nitrate and phosphate concentrations $(0.35$ and $0.18 \mu \mathrm{M}$, respectively; $\left.\mathrm{NO}_{3}{ }^{-}: \mathrm{PO}_{4}{ }^{3-}=1.9\right)$. A. tamarense net growth rates were very low in the non-amended treatment $(0.08 \pm$ 
$\left.0.09 \mathrm{~d}^{-1}\right)$. Phosphate addition significantly stimulated A. tamarense net growth rate $\left(>0.6 \mathrm{~d}^{-1}\right)$ over a very short burst, while nitrate addition resulted in an increase in the duration of the growth phase (4 d) along with a small, but not statistically significant, stimulation of the net growth rate $\left(0.22 \mathrm{~d}^{-1}\right.$; Fig. $8 \mathrm{~b}-\mathrm{d}$ and Table 1). The nitrate + phosphate addition induced an increase in both the duration of the $A$. tamarense growth phase $(7 \mathrm{~d})$ and in its net growth rate $\left(>0.3 \mathrm{~d}^{-1}\right)$; however, the growth rate was lower than in the phosphate addition experiment and not significantly different from the control. The evolution of the nutrient concentrations during the experiments (Fig. 8b,c) indicates that the short duration of the growth phase following phosphate addition could have been due to nitrate limitation (nitrate levels were $<0.2 \mu \mathrm{M}$ when $A$. tamarense growth stopped), while the termination of
A. tamarense growth following nitrate addition could have been due to phosphate limitation (phosphate levels were below the detection limit from Day 6 on). This is supported by the continuous growth observed when nitrate and phosphate were added together (Fig. 8d). Consequently, during the incubation experiments, phosphate availability appeared to control the $A$. tamarense growth rate, while nitrate availability controlled the duration of the growth phase and, thus, the biomass yield. This result gives additional support to the hypothesis proposed by Fauchot et al. (2005), which stipulates that $A$. tamarense growth may be limited by phosphate in the St. Lawrence estuary during red tide events. Combining the 2 data sets (1998 and 2000, see Fauchot et al. 2005), we found a $K_{\mathrm{s}}$ (phosphate concentration at which the $A$. tamarense growth rate is one half the maximum rate) of $0.26 \mu \mathrm{M}$.

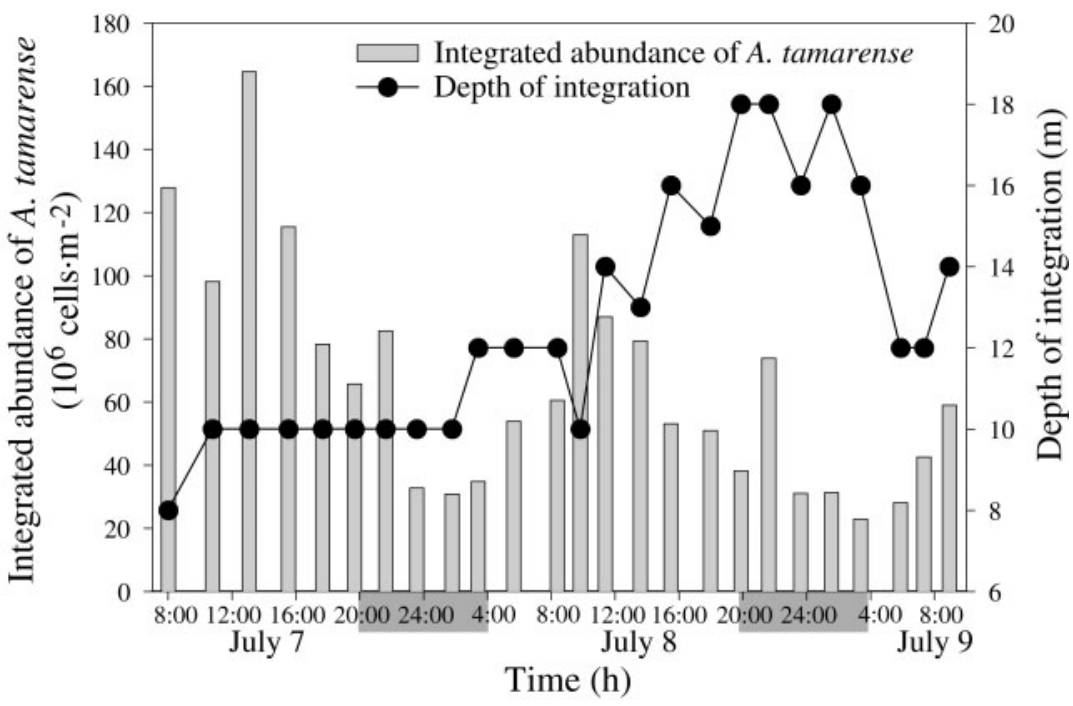

Fig. 6. Alexandrium tamarense. Temporal variations in the integrated abundance between the surface and 12 to $18 \mathrm{~m}$, and the maximum sampling depth (the depth of integration). The grey bars indicate night hours

Table 1. Alexandrium tamarense. Initial nutrient concentrations, net growth rates and the duration of exponential growth phases during nutrient addition experiments

\begin{tabular}{|lcccc|}
\hline Treatment & $\begin{array}{c}\text { Initial } \\
\mathrm{PO}_{4}{ }^{3-} \\
(\mu \mathrm{M})\end{array}$ & $\begin{array}{c}\text { Initial } \\
\mathrm{NO}_{3}{ }^{-} \\
(\mu \mathrm{M})\end{array}$ & $\begin{array}{c}\text { Net growth rate } \\
(\text { mean } \pm \mathrm{SD}) \\
\left(\mathrm{d}^{-1}\right)\end{array}$ & $\begin{array}{c}\text { Maximum } \\
\text { growth phase } \\
(\mathrm{d})\end{array}$ \\
\hline Control & 0.18 & 0.35 & $0.08 \pm 0.09$ & 2 \\
$\mathrm{PO}_{4}{ }^{3-}$ addition & 20.43 & 0.44 & $0.64 \pm 0.01^{\mathrm{b}}$ & 1 \\
$\mathrm{NO}_{3}{ }^{-}$addition & 0.18 & $64.26^{\mathrm{a}}$ & $0.22 \pm 0.00$ & 4 \\
$\mathrm{NO}_{3}{ }^{-}+\mathrm{PO}_{4}{ }^{3-}$ addition & 18.87 & 55.10 & $0.36 \pm 0.11$ & 7 \\
${ }^{\mathrm{a}} \mathrm{NO}_{3}{ }^{-}$concentration on Day 1, because initial $\mathrm{NO}_{3}{ }^{-}$concentration on Day 0 \\
was not available \\
bignificantly different from the control $(\mathrm{p}<0.05)$ \\
\hline
\end{tabular}

\section{DISCUSSION}

This study presents the first field evidence of the ability of Alexandrium tamarense to perform vertical migrations. Our results confirm the hypothesis of Passow (1991), who stated that vertical migrations of autotrophs can have 2 independent goals: (1) nocturnal migrations between the euphotic zone and deep nitrogen-rich layers to accumulate the necessary nitrogen for growth, and (2) daytime migrations within the euphotic zone to avoid harmful light intensity close to the surface. Here, we discuss the patterns and timing of these daytime and nighttime migrations, the different factors that may control them and their ecological implications for A. tamarense in the St. Lawrence estuary.

\section{Nocturnal vertical migrations of Alexandrium tamarense to deep nitrate-rich layers}

Alexandrium tamarense vertical migrations observed in the St. Lawrence estuary are consistent with migratory patterns previously reported for many dinoflagellates species (Cullen \& Horrigan 1981, Nishitani \& Chew 1984, Olsson \& Granéli 1991, Passow 1991) and especially with the results obtained during a laboratory experiment with 


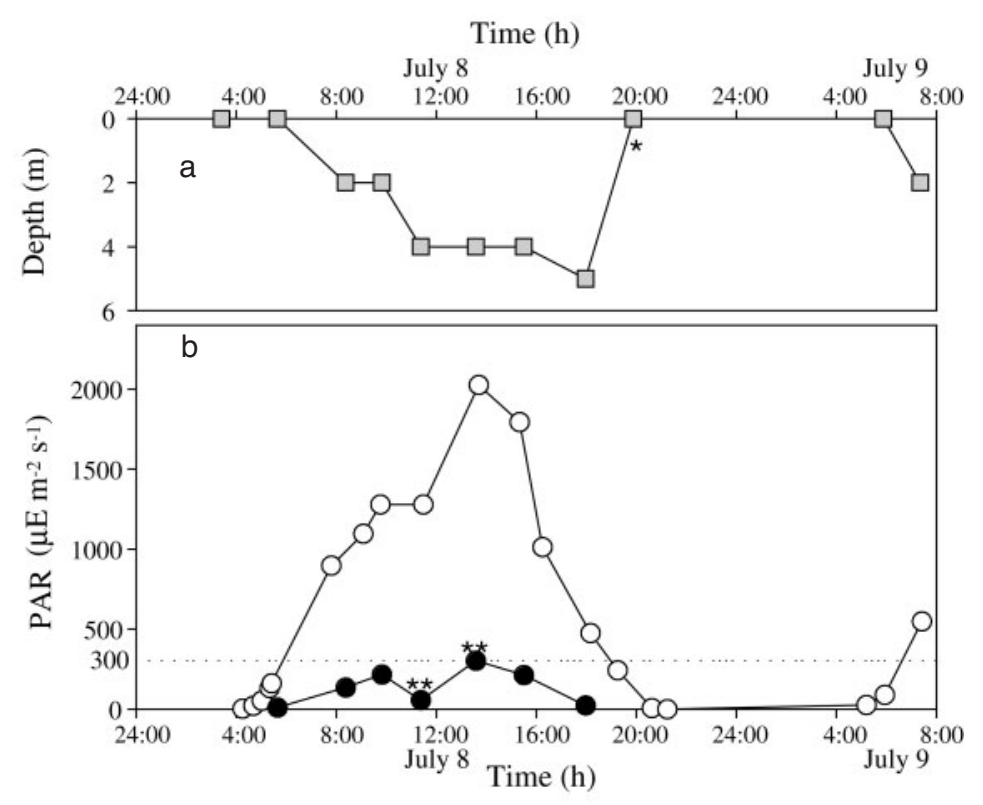

$\square-$ Depth of the maximum A. tamarense concentration -O- Incident PAR

- PAR at the depth of A. tamarense maximum concentration

Fig. 7. Alexandrium tamarense. Temporal variations in (a) the depth of the maximum $A$. tamarense concentration and (b) the incident light intensity and the light intensity at the depth of the maximum A. tamarense concentration on 8 July and during the morning of 9 July. * Maximum concentration in the surface layer, not considering the deep A. tamarense maximum. **These light intensities were estimated using the $K_{d}$ calculated from the light profiles measured at each of these sampling times, since we had no light measurement at the exact depth of the $A$. tamarense maximum concentration $(4 \mathrm{~m})$

an A. tamarense strain from the St. Lawrence estuary (MacIntyre et al. 1997). A. tamarense cells began their descent before sunset and they returned to the surface after sunrise as previously observed in the laboratory by MacIntyre et al. (1997).

Laboratory studies have already shown that dark uptake of nitrate can support the growth of several dinoflagellate species: Gonyaulax polyedra (Heaney \& Eppley 1981), Gymnodinium splendens (Cullen \& Horrigan 1981), Prorocentrum minimum, P. micans, Ceratium furca (Olsson \& Granéli 1991) and an Alexandrium tamarense strain from the St. Lawrence estuary (MacIntyre et al. 1997). During the present study, the depth at which A. tamarense reached maximum concentrations during the night coincided with the depth of the nitracline. Furthermore, despite a $\mathrm{NO}_{3}{ }^{2-}: \mathrm{PO}_{4}{ }^{3-}$ ratio of $1.9 \mathrm{in}$ surface waters, the results of the nutrient addition experiment indicate that the $A$. tamarense growth rate may be phosphate-, not nitrate-limited. These results suggest that $A$. tamarense cells were able to fulfill their nitrogen requirement while migrating to the deep lay- ers during the night. However, in contrast to the raphidophyte Chattonella antiqua (Watanabe et al. 1991), the uptake of nitrate and phosphate does not seem to be synchronized in A. tamarense cells, maybe because they do not migrate deep enough to reach the phosphacline and/or because they are not capable of dark phosphate uptake. Along with the cell maximum at depth during the night, we also observed a peak concentration of A. tamarense in the surface layer. In their labora-

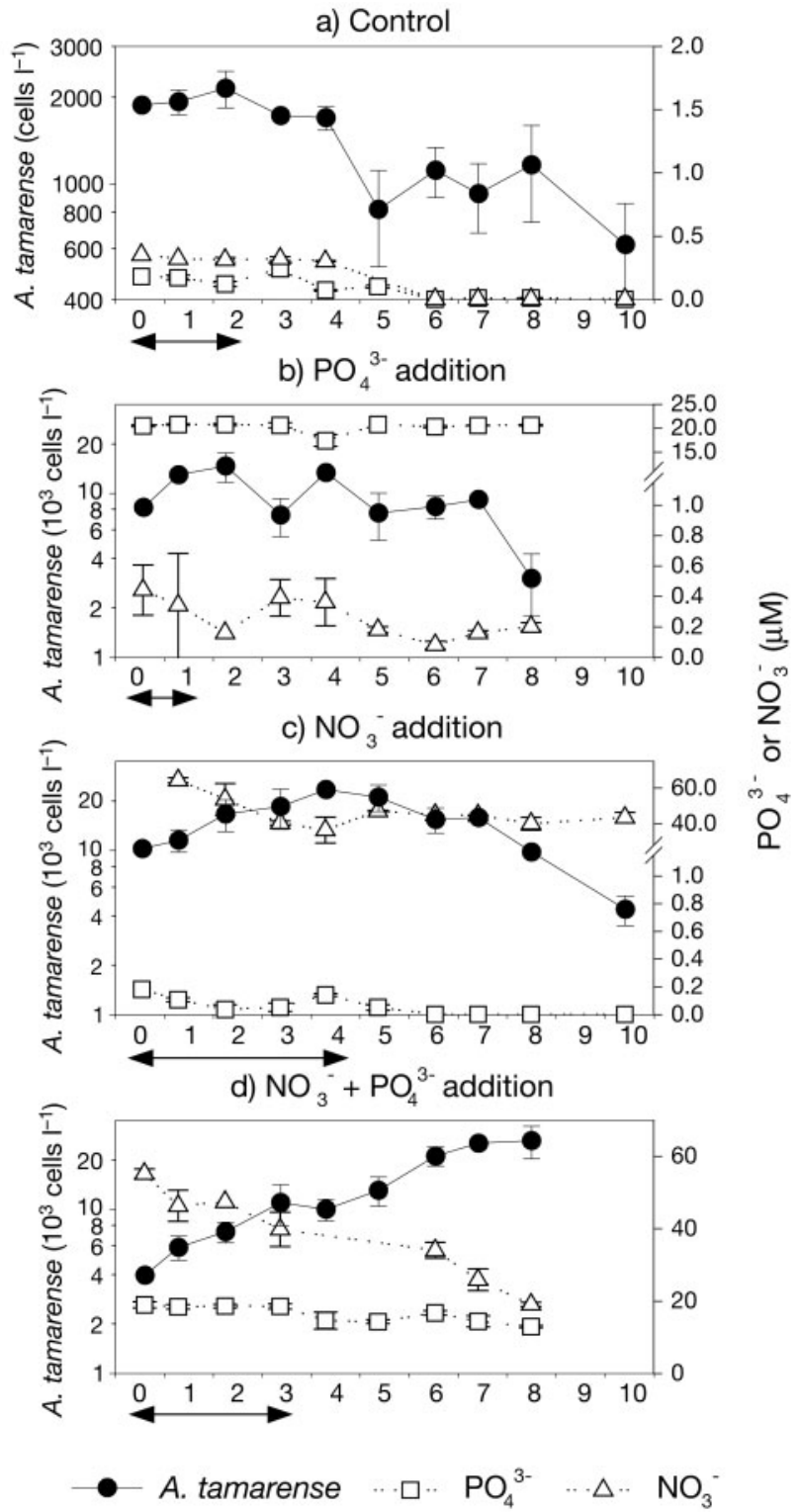

Fig. 8. Alexandrium tamarense. Temporal variations in abundance of phosphate and nitrate during the nutrient addition experiments for the different treatments: (a) control; (b) phosphate addition; (c) nitrate addition; and (d) nitrate + phosphate addition. Note the log scale for the $y$-axis. Arrows indicate the periods during which $A$. tamarense net growth rates were calculated for each treatment (see Table 1) 
tory study, MacIntyre et al. (1997) also observed higher cell concentrations at the surface along with a deep maximum during the night under nitrate-depleted conditions. Vertical migrations can be controlled by the nutritional status of dinoflagellate cells (Kamykowski \& Yamazaki 1997, MacIntyre et al. 1997). The persistence of a sub-population close to the surface at night, therefore, suggests that these cells were not nutrientstressed. In a nitrogen-depleted euphotic layer, this is possible if newly divided A. tamarense cells are able to store enough nitrogen at depth during the first night to complete their cell cycle and divide. Collos et al. (2004) found that $A$. catenella could take up enough nitrogen in $2 \mathrm{~h}$ to satisfy its growth requirements for $24 \mathrm{~h}$. Cullen \& MacIntyre (1998) reported that several phytoplankton species migrate between the nutricline and surface waters with a period of more than $1 \mathrm{~d}$. As a consequence, the periodicity of vertical migration for an $A$. tamarense cell could be of the order of a generation time. Energetically speaking, this strategy would be economic (Kamykovzki \& Yamazaki 1997); however, it may still have a cost since $A$. tamarense cells at the surface during the night coexist with potential grazers that migrate to surface waters at night.

Vertical migrations are not only relevant in terms of nutrient sources for Alexandrium tamarense growth, they can also affect the advection of blooms and especially their retention time in the environment where they develop (Anderson \& Stolzenbach 1985). In that respect, the presence of $A$. tamarense cells at the surface during the night and the maximum depth that the cells reach during their migration are important parameters. During both nights of the survey, $A$. tamarense cells reached the nitracline at $12 \mathrm{~m}$. The decrease in total integrated $A$. tamarense abundance during the survey and especially during the night suggests that $A$. tamarense might have migrated deeper than $12 \mathrm{~m}$. Our estimated swimming speed of $A$. tamarense cells of ca. $2 \mathrm{~m} \mathrm{~h}^{-1}$ is in agreement with previous estimates for Gonyaulax polyedra and Ceratium furca (Heaney \& Eppley 1981), and Gonyaulax catenata (Passow 1991). Considering a migration speed of $2 \mathrm{~m} \mathrm{~h}^{-1}$ over $15 \mathrm{~h}$, we calculated that $A$. tamarense cells could reach a depth of 15 to $20 \mathrm{~m}$ in 1 night. This must be taken into account when trying to understand the influence of advection on bloom development in the St. Lawrence estuary. Given the estuarine circulation prevailing in this system, phytoplanktonic species which are able to migrate and, therefore, to spend part of the day in deeper layers could be less affected by the flushing of surface waters out of the estuary. We, therefore, hypothesize that the migration of A. tamarense cells to deep layers during several hours of the day might increase the residence time of the blooms in the estuary.

\section{Daytime vertical migrations: avoidance of high light intensities}

In addition to nocturnal migrations to deep nitrate pools, we observed a downward movement of Alexandrium tamarense cells from the surface layer into the subsurface and intermediate layers in the late morning and in the afternoon. A. tamarense cells aggregated close to the surface only when incident light intensity was lower than $300 \mu \mathrm{mol}$ photons $\mathrm{m}^{-2}$ $\mathrm{s}^{-1}$. Above this threshold, the cells formed a subsurface maximum at a depth where light intensity was around $300 \mu \mathrm{mol}$ photons $\mathrm{m}^{-2} \mathrm{~s}^{-1}$ or lower. $A$. tamarense seems, therefore, to actively avoid light intensities higher than a specific threshold. This behavior has already been described for several dinoflagellate species (Cullen \& Horrigan 1981, Heaney \& Eppley 1981, Passow 1991). However, in the laboratory study of MacIntyre et al. (1997), A. tamarense strain Pr18b from the St. Lawrence estuary always aggregated close to the surface during the day. This discrepancy is probably due to the relatively low irradiance used during their experiment (390 $\mu$ mol photons $\mathrm{m}^{-2} \mathrm{~s}^{-1}$ at the surface). The value of $300 \mu \mathrm{mol}$ photons $\mathrm{m}^{-2} \mathrm{~s}^{-1}$ is comparable to the light intensities at which Gonyaulax catenata (100 $\mu \mathrm{mol}$ photons $\mathrm{m}^{-2} \mathrm{~s}^{-1}$, Passow 1991), G. polyedra (150 $\mu$ mol photons $\mathrm{m}^{-2} \mathrm{~s}^{-1}$, Heaney \& Eppley 1981) and Gymnodinium splendens (250 $\mu$ mol photons $\mathrm{m}^{-2}$ $\mathrm{s}^{-1}$, Cullen \& Horrigan 1981) have been reported to accumulate. Cullen \& Horrigan (1981) found that this threshold corresponded to the saturating light intensity for G. splendens photosynthesis. This suggests that the saturating light intensity for $A$. tamarense photosynthesis in the St. Lawrence estuary during our study was ca. $300 \mu \mathrm{mol}$ photons $\mathrm{m}^{-2} \mathrm{~s}^{-1}$. This is in agreement with the laboratory study of Parkhill \& Cembella (1999) where the maximum growth rate of A. tamarense clone Pr18b (isolated from the lower St. Lawrence estuary) was recorded at a light intensity of $230 \mu \mathrm{mol}$ photons $\mathrm{m}^{-2} \mathrm{~s}^{-1}$, while some growth inhibition was possible at $470 \mu \mathrm{mol}$ photons $\mathrm{m}^{-2} \mathrm{~s}^{-1}$. Overall, these results show that $A$. tamarense in the St. Lawrence estuary adjusts to daily fluctuations in light intensity using its motile capacity. This strategy may allow $A$. tamarense cells to optimize their growth since the energetic cost of swimming is low (Richardson et al. 1983) and vertical migrations dispense the cells from developing physiological adaptations to high irradiance levels (Passow 1991, Cullen \& MacIntyre 1998). Our results also confirm that dinoflagellates are not strictly positive or negative phototactic organisms, but that phototaxis may depend on the time of day and light intensity (Blasco 1978). 


\section{Nutrient control of Alexandrium tamarense growth rate}

The results from the nutrient addition experiment show that the Alexandrium tamarense growth rate in the St. Lawrence estuary may be limited by phosphate as hypothesized by Fauchot et al. (2005). The low $\mathrm{NO}_{3}{ }^{-}: \mathrm{PO}_{4}{ }^{3-}$ ratio in surface waters, the observations of vertical migrations to deep layers during the night and the high affinity of $A$. tamarense for phosphate confirm the hypothesis that the ability of $A$. tamarense to reach deep nitrate pools pushes this species towards phosphate limitation in the St. Lawrence estuary. Adding nitrate + phosphate led to a weaker (not significant) stimulation of the A. tamarense net growth rate than adding only phosphate. In the St. Lawrence estuary, $A$. tamarense cells are probably adapted to taking up nitrate in the dark at night, and phosphate during the day. The difference in net growth rate between the phosphate and nitrate + phosphate addition experiments may result from the necessary adaptation of cellular metabolism to the sudden and simultaneous availability of nitrate and phosphate in the light. As previously hypothesized by Fauchot et al. (2005), our results suggest that the growth rate of $A$. tamarense in the St. Lawrence estuary is controlled by phosphate availability, while the biomass reached during a bloom depends on nitrate availability and on the cells ability to perform vertical migrations.

The $K_{\mathrm{s}}$ of $0.26 \mu \mathrm{M}$ calculated from Alexandrium tamarense growth rate data from this study and another study in 1998 (Fauchot et al. 2005) is lower than the $K_{\mathrm{s}}$ values of 1 and $1.68 \mu \mathrm{M}$ reported for 2 other A. tamarense strains (Frangópulos et al. 2004). This apparent high affinity for phosphate exhibited by $A$. tamarense in the St. Lawrence estuary could represent an adaptation to the low-phosphate concentrations encountered in surface waters where the cells develop and to the ability of $A$. tamarense to use deep nitrogen pools.

\section{CONCLUSION}

Our results show that Alexandrium tamarense cells perform vertical migrations in the St. Lawrence estuary. This ability may give them an advantage over other phytoplankton species since nocturnal migrations to the nitracline may allow A. tamarense cells to fulfill their nitrogen requirements even when nitrate is exhausted in surface waters. Furthermore, during the day, A. tamarense cells can avoid harmful light intensities close to the surface by migrating and concentrating at the depth of their optimal light intensity. However, the ability of $A$. tamarense to reach deep nitrate pools pushes this species towards phosphate limitation. Consequently, during an A. tamarense bloom in the St. Lawrence estuary, the growth rate is apparently controlled by phosphate availability in surface waters, but the maximum biomass achieved depends on nitrate availability, and thus partly on the ability of $A$. tamarense to perform vertical migrations. The dependence of $A$. tamarense growth on vertical migration provides a new explanation for the well-known sensitivity of this organism to vertical mixing. Previous studies already suggested that wind-induced mixing can have a directly damaging effect on cellular growth (White 1976, Juhl et al. 2001, Fauchot et al. 2005). Our results show that, in addition, mixing could negatively influence the development of $A$. tamarense blooms in the St. Lawrence estuary by preventing the cells from aggregating at the depth of their optimal light intensity and accessing the deep nitrate pool at night. This may partially explain the negative relationship observed between $A$. tamarense abundance, growth rate and wind speed observed in the St. Lawrence estuary (Weise et al. 2002, Fauchot et al. 2005).

Acknowledgements. The authors thank the crew of the C.C.G.S. 'Martha L. Black'; J.-Y. Couture, R. Desmarais, A. Gagné, K. Picard, R. Gagnon, R. Pigeon and A. M. Weise for field and laboratory assistance; M.-L. Dubé for nutrient analyses; J.-Y. Couture, S. Lessard and L. Bérard-Therriault for Alexandrium tamarense enumeration and B. Gouteux for help with the statistical analyses. J.F. received a postgraduate fellowship from the Institut des Sciences de la Mer (Université du Québec à Rimouski, Québec, Canada). This study was conducted within the CLIVHAB project (Climate Variability and Harmful Algal Blooms) supported by the Science Strategic Fund of Fisheries and Oceans Canada and the Government of Canada's Climate Change Action Fund. The project also benefited from NSERC grants to M.L. and S.R.

\section{LITERATURE CITED}

Anderson DM, Stolzenbach KD (1985) Selective retention of two dinoflagellates in a well-mixed estuarine embayment: the importance of diel vertical migration and surface avoidance. Mar Ecol Prog Ser 25:39-50

Blasco D (1978) Observations on the diel migration of marine dinoflagellates off the Baja California Coast. Mar Biol 46: $41-47$

Blasco D, Levasseur M, Bonneau E, Gelinas R, Packard TT (2003) Patterns of paralytic shellfish toxicity in the St. Lawrence region in relationship with the abundance and distribution of Alexandrium tamarense. Sci Mar 67: 261-278

Collos Y, Gagne C, Laabir M, Vaquer A, Cecchi P, Souchu P (2004) Nitrogenous nutrition of Alexandrium catenella (Dinohpyceae) in cultures and in Thau lagoon, southern France. J Phycol 40:96-103

Cullen JJ, Horrigan SG (1981) Effects of nitrate on the diurnal vertical migration, carbon to nitrogen ratio, and the photosynthetic capacity of the dinoflagellate Gymnodinium splendens. Mar Biol 62:81-89 
Cullen JJ, MacIntyre JG (1998) Behavior, physiology, and the niche of depth-regulating phytoplankton. In: Anderson DM, Cembella AD, Hallegraeff GM (eds) Physiological ecology of harmful algal blooms. NATO ASI Series, Vol G41. Springer-Verlag, New York, p 559-579

Donaghay PL, Osborn TR (1997) Toward a theory of biological-physical control of harmful algal bloom dynamics and impacts. Limnol Oceanogr 42:1283-1296

Fauchot J, Levasseur M, Roy S, Gagnon R, Weise A (2005) Environmental factors controlling Alexandrium tamarense (Dinophyceae) growth rate during a red tide event in the St. Lawrence estuary (Canada). J Phycol 41:263-272

Frangópulos M, Guisande C, deBlas E, Maneiro I (2004) Toxin production and competitive abilities under phosphorus limitation of Alexandrium species. Harmful Algae 3: 131-139

Heaney SI, Eppley RW (1981) Light, temperature and nitrogen as interacting factors affecting diel vertical migrations of dinoflagellates in culture. J Plankton Res 3:331-344

Juhl AR, Trainer VL, Latz M (2001) Effect of fluid shear and irradiance on population growth and cellular toxin content of the dinoflagellate Alexandrium fundyense. Limnol Oceanogr 46:758-764

Kamykowski D, Yamazaki H (1997) A study of metabolisminfluenced orientation in the diel vertical migration of marine dinoflagellates. Limnol Oceanogr 42:1189-1202

Lund JWG, Kipling C, Le Cren ED (1958) The inverted microscope method of estimating algal numbers and the statistical basis of estimation by counting. Hydrobiologia 11: $143-178$

MacIntyre JG, Cullen JJ, Cembella AD (1997) Vertical migration, nutrition and toxicity in the dinoflagellate Alexandrium tamarense. Mar Ecol Prog Ser 148:201-216

Editorial responsibility: Otto Kinne (Editor-in-Chief), Oldendorf/Luhe, Germany
Nishitani L, Chew KK (1984) Recent developments in paralytic shellfish poisoning research. Aquaculture 39:317-329

Olsson P, Granéli E (1991) Observations on diurnal vertical migration and phased cell division for three coexisting marine dinoflagellates. J Plankton Res 13:1313-1324

Parkhill JP, Cembella AD (1999) Effects of salinity, light and inorganic nitrogen on growth and toxigenicity of the marine dinoflagellate Alexandrium tamarense from northeastern Canada. J Plankton Res 21:939-955

Passow U (1991) Vertical migrations of Gonyaulax catenata and Mesodinium rubrum. Mar Biol 110:455-463

Richardson K, Beardall J, Raven JA (1983) Adaptation of unicellular algae to irradiance: an analysis of strategies. New Phytol 93:157-191

Therriault JC, Painchaud J, Levasseur M (1985) Factors controlling the occurrence of Protogonyaulax tamarensis and shellfish toxicity in the St. Lawrence estuary: freshwater runoff and the stability of the water column. In: Anderson DM, White AW, Baden DG (eds) Toxic dinoflagellates. Elsevier Science Publishing, New York, p 141-146

Watanabe M, Kohata K, Kimura T (1991) Diel vertical migration and nocturnal uptake of nutrients by Chattonella antiqua under stable stratification. Limnol Oceanogr 36: 593-602

Weise AM, Levasseur M, Saucier FJ, Senneville S and 5 others (2002) The link between precipitation, river runoff, and blooms of the toxic dinoflagellate Alexandrium tamarense in the St. Lawrence. Can J Fish Aquat Sci 59:464-473

White AW (1976) Growth inhibition caused by turbulence in the toxic marine dinoflagellate Gonyaulax excavata. J Fish Res Board Can 33:2598-2602

Zar JH (1984) Biostatistical analysis. Prentice-Hall, Englewood Cliffs, NJ

Submitted: October 17, 2004; Accepted: March 8, 2005

Proofs received from author(s): June 21, 2005 